\title{
Peran Tokoh Agama Islam, Hindu, dan Kristen dalam Menjaga Kerukunan Beragama di Desa Banuroja, Gorontalo
}

\author{
The Role of Islam, Hindu, and Christian Leaders in Maintaining Religious Harmony \\ in Banuroja Village, Gorontalo
}

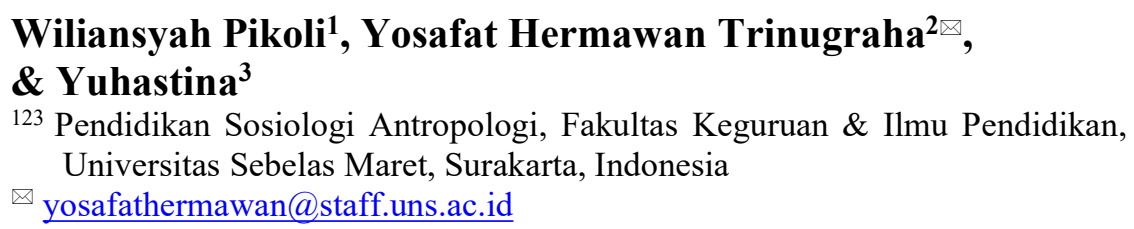

\begin{abstract}
This study aims to determine the role of Islamic, Christian (Protestant and Catholic) and Hindu religious leaders in maintaining inter-religious harmony in Banuroja Village, Randangan District, Pohuwato Regency, Gorontalo Province. This study uses a qualitative research method with a case study approach. Data collection techniques were carried out through observation, interviews and documentation. The results of this study indicate that the roles of religious leaders are different but the goal is the same, namely maintaining harmony between religious believers, the role of religious leaders is to teach people to help each other without discriminating, teach openness, teach three sacred actions (holy thought, utterance, and behavior), giving understanding in terms of maintaining communication between others, inviting the community to participate in community service, inviting other people to help when they are holding activities, and always warning the public not to be easily provoked by religious issues. Keywords: Banuroja village; religious harmony; religious leaders; religious people; role.
\end{abstract}

Abstrak: Penelitian ini bertujuan untuk mengetahui bagaimana peran dari tokoh agama Islam, Kristen (Protestan dan Katolik), dan Hindu dalam menjaga kerukunan antarumat beragama di Desa Banuroja, Kecamatan Randangan, Kabupaten Pohuwato, Provinsi Gorontalo. Penelitian ini menggunakan metode penelitian kualitatif dengan pendekatan studi kasus. Teknik pengumpulan data dilakukan melalui observasi, wawancara dan dokumentasi. Hasil penelitian ini menunjukan bahwa peran para tokoh agama berbeda-beda tetapi tujuannya sama yaitu menjaga kerukunan antarumat beragama, peran para tokoh agama yaitu mengajarkan masyarakat untuk saling tolong menolong tanpa membeda-bedakan,mengajarkan sikap keterbukaan, mengajarkan tiga perbuatan suci (berfikir suci, berkata suci, dan berperilaku suci), memberi pemahaman dalam hal menjaga komunikasi antar sesama, mengajak masyarakat untuk ikut kerja bakti, mengajak untuk ikut membantu umat lain jika sedang mengadakan kegiatan, dan selalu memperingatkan masyarakat untuk tidak mudah terpancing mengenai isu-isu yang berbau agama.

Kata kunci: Desa Banuroja; kerukunan beragama; masyarakat relijius; pemimpin agama; peran. 


\section{Pendahuluan}

Keberagaman agama adalah sebuah realitas sosial yang ada di Indonesia. Pada saat ini secara resmi terdapat enam agama yang diakui oleh pemerintah. Hal ini menjadi kebanggaan tersendiri bahwa masyarakat Indonesia dapat hidup berdampingan meski terdapat banyak perbedaan di dalamnya. Akan tetapi keragaman yang dimiliki Indonesia ini juga bisa berpotensi menimbulkan permasalahan ketika masyarakat tidak dapat saling menghargai perbedaan satu sama lain. Masih adanya prasangka buruk dan tidak adanya sikap toleransi di dalam suatu masyarakat dapat dengan mudah memunculkan konflik, apalagi yang menyangkut dengan hal-hal sensitif seperti agama. Hal tersebut sejalan dengan hasil penelitian dari Aziz yang menunjukkan bahwa munculnya sebuah masalah atau konflik disebabkan oleh prasangka antara kelompok dalam masyarakat yang semakin kuat karena adanya perbedaan agama dan budaya, di mana antara satu kelompok dengan kelompok lainnya tidak saling peka dan mengetahui budaya di tiap-tiap agama yang ada. ${ }^{1}$

Lebih jauh ketika berbicara perihal agama sebagai sistem nilai yang di dalamnya terdapat berbagai aturan dan petunjuk yang mengatur tindakan maupun pola perilaku manusia ternyata tidak seindah konsep awalnya. Realitas yang ada menunjukan bahwa persoalan yang menyangkut dengan perbedaan masih sering terjadi. ${ }^{2}$ Masih adanya sikap eksklusif, persoalan terkait etnosentrisme bahkan isu mengenai diskriminasi adalah hal yang lumrah dan sering terjadi. Setiap agama mempunyai keyakinan sendiri-sendiri dalam melihat dunia, hal itulah yang menjadi akar permasalahan mengapa persoalan terkait etnosentrisme selalu muncul. Hal tersebut berlandaskan pada sikap intoleran dari tiap-tiap pemeluk agama yang ada tersebut. ${ }^{3}$

Adanya berbagai tindakan kekerasan, perpecahan, sengketa, hingga pertumpahan darah adalah bukti nyata dari konflik yang mengatasnamakan agama. Seperti konflik agama yang pernah terjadi di Poso antara umat Islam dan Kristen yang bahkan terjadi hingga beberapa kali yakni pada tahun 1992, 1995, 1998, 2000 dan 2001. Kemudian juga konflik antar aliran agama yang terjadi antara Sunni dan Syiah di Jawa Timur pada tahun 2012. Tidak hanya itu, masih banyak terdapat konflik antaragama lainnya seperti yang terjadi di Ambon dan Situbondo, lalu kasus pembakaran rumah ibadah Kaum Ahmadiyah dan Kaum Gafatar serta kasus pembakaran masjid di Tolikara Papua. ${ }^{4}$

Melihat dari adanya masalah maupun konflik yang dilatarbelakangi oleh agama, maka dirasa perlu untuk menciptakan kerukunan antarumat beragama dan menjaganya agar kehidupan dapat berjalan dengan damai dan harmonis. ${ }^{5}$ Hal ini selaras juga dengan apa yang peneliti temukan di Desa Banuroja yang terletak di Kecamatan Randangan, Kabupaten Pohuwato,

1 Zahara Aziz, Amla Salleh, and Hardiana Ema Ribu, "A Study of National Integration: Impact of Multicultural Values," Procedia - Social and Behavioral Sciences 7, no. 2 (2010): 691-700, https://doi.org/10.1016/j.sbspro.2010.10.094.

2 Agus Setyawan, "Dakwah Yang Menyelamatkan: Memaknai Ulang Hakikat Dan Tujuan Da'wah Islamiyah," Al-Adabiya: Jurnal Kebudayaan Dan Keagamaan 15, no. $02 \quad$ (2020): 189-99, https://doi.org/https://doi.org/10.37680/adabiya.v15i02.487.

${ }^{3}$ Wahab, Harmoni Di Negeri Seribu Agama (Membumikan Teologi Dan Fikih Kerukunan). Jakarta: PT Elex Media Komputindo, 2015.

${ }^{4}$ Inayatul Ulya, "Pendidikan Islam Multikultural Sebagai Resolusi Konflik Agama Di Indonesia," Fikrah 4, no. 1 (2016): 20, https://doi.org/10.21043/fikrah.v4i1.1663.

5 Suryo Adi Sahfutra, "Konflik Dan Bina Damai Masyarakat Multirelijius: Studi Masyarakat Turgo Lereng Merapi Yogyakarta," MUHARRIK: Jurnal Dakwah Dan Sosial 2, no. 2 (November 13, 2019): 71-97, https://doi.org/10.5281/ZENODO.3540507. 
Provinsi Gorontalo. Berdasarkan hasil observasi peneliti, didapatkan informasi bahwa Desa Banuroja ini dihuni oleh 12 etnis yaitu etnis Bali, Sasak, Jawa, Gorontalo, Sunda, Minahasa, Bugis, Batak, Flores, Betawi, Toraja, dan Bajau. Desa ini juga terkenal dengan penduduknya yang memeluk tiga, atau empat agama yakni Islam, Hindu, dan Kristen, baik Protestan maupun Katolik. Ragam etnis dan agama yang ada di Desa Banuroja membuat desa ini dapat pula dijuluki sebagai miniaturnya Indonesia.

Ditemukan pula fakta bahwa tempat ibadah yang ada di Desa Banuroja saling berdekatan satu sama lain, namun itu tidak menjadi sebuah persoalan. Masyarakat yang telah beradaptasi dengan situasi seperti itu sudah tidak menganggap lagi itu sebagai hal yang menganggu mereka, dari sini dapat dilihat bagaimana toleransi yang ada pada masyarakat di Desa Banuroja telah terbangun dengan baik di dalam diri mereka. Fakta lainnya yang ada di Desa Banuroja adalah terdapat tradisi unik yang sudah menjadi kebiasaan masyarakat, yakni saling mengundang dan mengunjungi ketika perayaan hari besar keagamaan dari tiap-tiap agama yang ada di desa ini.

Toleransi dan kerukunan yang ada di Desa Banuroja sekarang ini merupakan hasil dari proses adaptasi masyarakat sejak desa ini dibentuk. Hal ini tidak terlepas dari peran para tokoh agama dalam mengajak masyarakat untuk sama-sama menumbuhkan sikap toleransi dalam keberagaman. Peran dari para tokoh agama dalam menjaga kerukunan sangat dirasakan oleh masyarakat. Mereka mengambil langkah-langkah guna meminimalisir munculnya masalah dengan saling bekerja sama untuk membuat kondisi Desa Banuroja tetap dalam keadaan rukun dan damai, termasuk ketika Konflik Poso yang pernah terjadi beberapa tahun yang lalu, diusahakan konflik tersebut tidak sampai merembet ke Banuroja. Selain itu, diungkapkan oleh tokoh agama Kristen di Desa Banuroja bahwa masalah lain yaitu masalah terkait dengan peristiwa Pilkada DKI Jakarta tahun 2017 silam yang sempat menjadi isu nasional. Setelah mendengar masalah atau konflik agama yang terjadi melalui tayangan di berita nasional tersebut, para tokoh agama berkoordinasi dan semakin gencar mengingatkan masyarakat agar lebih meningkatkan sikap toleransinya sehingga masalah tersebut tidak sampai membuat masyarakat Desa Banuroja terpancing yang ujungnya dapat memunculkan masalah baru.

Pentingnya mengutamakan rasa kekeluargaan membuat kerukunan di desa ini terjaga sejak dulu hingga sekarang. Hal-hal yang sifatnya mengganggu kerukunan dapat langsung diatasi bersama sehingga desa pun jauh dari yang namanya masalah atau konflik yang berbau agama. Dalam kehidupan masyarakat, kehadiran para tokoh agama yang ada menjadi salah satu pendukung terciptanya kehidupan yang rukun dan damai. Para tokoh agama menjadi agent of change atas tindakan dan pola perilaku masyarakat. Di sinilah para tokoh agama mengambil perannya untuk menanamkan sikap toleransi agar kerukunan antarumat beragama di Desa Banuroja tetap terjaga dengan baik. Lantas, bagaimana kemudian peran tokoh agama dalam menjaga kerukunan antarumat beragama di Desa Banuroja, Kecamatan Randangan, Kabupaten Pohuwato, Provinsi Gorontalo?

Terdapat beberapa penelitian yang sebelumnya telah dilakukan dalam melihat peran tokoh agama dalam menjaga kerukunan antarumat beragama yang menunjukan beberapa fakta. Pertama adalah penelitian Baihaqi menunjukkan peran tokoh agama dalam menjaga kerukunan antarumat beragama dengan menerapkan pinsip-prinsip komunikasi kelompok seperti interaksi sosial, bekerja sama dan gotong royong dalam berbagai bidang. Di antaranya sosial kemasyarakatan, keagamaan, sosial individu, musyawarah antar umat seagama dan umat beragama lain, dan 
memiliki rasa kepedulian terhadap sesama maupun terhadap lingkungan yang memiliki kemajemukan agama. ${ }^{6}$ Selanjutnya penelitian Wibowo dan Yani mengenai pandangan masyarakat terhadap pemenuhan hak dan kewajiban yang dilakukan tokoh agama telah sesuai dengan harapan masyarakat yaitu mampu menjalankan perannya dalam kegiatan sosial dan kegiatan keagamaan. Masyarakat menjadikan tokoh agama sebagai panutan dalam menjaga kerukunan dan keharmonisan antar umat beragama. Kerukunan yang ada dipengaruhi oleh interaksi tokoh agama saat perayaan hari besar dari tiap-tiap agama, saling membantu antaragama, pekerjaan, pemimpin spiritual, menjaga kerukunan sesama agama dan juga antaragama. ${ }^{7}$

Kemudian penelitian yang dilakukan Lestari tentang peran dari tokoh masyarakat dan tokoh agama dalam menerapkan pendidikan multikultural antaragama di Desa Menjing, Kabupaten Karanganyar melalui beragam kegiatan. Bentuk kegiatannya yaitu pertemuan rutin tiga bulan sekali antartokoh masyarakat dan tokoh agama, gotong royong dan kegiatan sosial tanpa membedakan status dan agama, upacara kematian, serta peringatan hari besar keagamaan dimana tempat parkir dan penjaganya dibantu dari berbagai umat antar agama. ${ }^{8}$ Selanjutnya, penelitian Wasil mengenai peran pemuka agama Islam dan Katolik dalam memelihara kerukunan di Desa Pabian, Sumenep, Madura yakni dengan cara melakukan internalisasi teologi tentang kerukunan. Di sini masyarakat yang terdiri dari agama Islam dan Katolik diberi pemahaman keagamaan terkait adanya berbagai perbedaan yang merupakan kehendak dari Tuhan, sehingga masyarakat dapat saling menerima dan menghormati perbedaan yang kemudian dapat menciptakan kerukunan antar umat beragama. Kemudian pemeliharaan kerukunan juga dilakukan dengan cara menyebarkan paham keagamaan yang moderat melalui media. Tiap agama menyebarkan paham moderat melalui khotbah dalam setiap peribadatannya, ibadah mingguan oleh agama Katolik dengan menekankan pada ajaran cinta kasih kepada sesama manusia. Kemudian untuk agama Islam adalah dengan memberikan contoh melalui khotbah jum'at, majelis taklim serta ceramah tentang bagaimana sifat dan perilaku Nabi Muhammad SAW. ${ }^{9}$

Selain itu, terdapat beberapa penelitian terdahulu yang mengambil latar belakang Desa Banuroja, salah satu di antaranya adalah penelitian Noe dkk yang berusaha mengkaji aktivitas masyarakat terkait dengan nilai-nilai karakter bangsa yang mewujudkan multikulturalisme dan integrasi sosial pada masyarakat Banuroja. Perwujudan itu dilakukan dengan tiga cara, yaitu asimilasi, toleransi beragama dengan menghargai kegiatan etnis/agama lain dengan cara

6 Muhamad Abid Baihaqi, "Peran Tokoh Agama Dalam Menjaga Kerukunan Antarumat Beragama (Komunikasi Kelompok Pada Dusun Thekelan, Desa Batur, Kecamatan Getasan, Kabupaten Semarang Tahun 2018)." Fakultas Dakwah, Institut Agama Islam Negeri Salatiga, 2018. http://erepository.perpus.iainsalatiga.ac.id/id/eprint/4402

7 Tri Wibowo; Muhammad Turhan Yani, "Peran Tokoh Agama Dalam Menjaga Kerukunan Antar Umat Beragama Di Desa Sekaran Kecamatan Kayen Kidul Kabupaten Kediri,” Kajian Moral Dan Kewarganegaraan 02, no. 04 (2016): 844-58. Kajian Moral dan Kewarganegaraan 2, no. 4 (2016): 844-858

${ }^{8}$ Dwi Lestari, "Upaya Tokoh Masyarakat Dan Tokoh Agama Dalam Menerapkan Pendidikan Multikultural Antaragama Di Desa Menjing Kecamatan Jenawi Kabupaten Karanganyar Tahun 2019. ” Fakultas Ilmu Tarbiyah, Institut Agama Islam Negeri Surakarta, 2019. Pendidikan multikultural-multirelijius juga sebagaimana dipraktikkan oleh komunitas Young Interfaith Peacemaker Community Indonesia yang menyelenggarakan kegiatan dialog Scriptural Reasoning, lihat di Gabriel James Angkouw and Iky Sumarthina Putri Prayitno, "Scriptural Reasoning: Peran Kitab Keagamaan Dalam Pendidikan Agama Multikultural Di Young Interfaith Peacemaker Community Indonesia," Al-Adabiya: Jurnal Kebudayaan Dan Keagamaan 15, no. 01 (June 5, 2020): 69-91, https://doi.org/10.37680/adabiya.v15i01.410.

${ }^{9}$ Wasil, "Peran Pemuka Agama Dalam Memelihara Kerukunan: Studi Kasus Hubungan Islam Dan Katolik Di Desa Pabian Kabupaten Sumenep.” Pascasarjana, Fakultas Ushuluddin, Universitas Islam Negeri Syarif Hidayatullah, 2018. http://repository.uinjkt.ac.id/dspace/handle/123456789/40292 
menghadirinya, dan gotong royong. Kemudian juga dilakukan pembinaan melalui kegiatan nasional dan keagamaan di masyarakat, nasehat orang tua dalam keluarga, pendidikan kewarganegaraan di sekolah, keteladanan oleh tokoh masyarakat termasuk tokoh suku, agama, dan pemuda. ${ }^{10}$ Berbeda dengan penelitian tersebut, pada penelitian ini tokoh agama dan masyarakat Banuroja dijadikan sebagai subjek utama untuk diteliti yakni dengan melihat peran para tokoh agama untuk menjaga kerukunan antarumat beragama di Desa Banuroja.

Dari paparan di atas dapat diketahui bahwa pada penelitian terdahulu hanya terbatas pada hubungan kerukunan antara agama Islam dengan Kristen saja, sedangkan dalam penelitian ini akan fokus pada tiga agama yaitu Islam, Kristen (Protestan dan Katolik), dan Hindu. Dalam penelitian terdahulu juga ditemukan bahwa para tokoh agama menjalankan tugasnya di bawah lembaga formal seperti Forum Kerukunan Umat Beragama (FKUB), sedangkan dalam penelitian ini para tokoh agama menjalankan tugas dan kewajibannya secara mandiri dan lebih informal, salah satunya karena di Desa Banuroja belum terbentuk FKUB. Terkait lokasi dalam penelitian ini juga terdapat suatu keunikan yaitu Desa Banuroja ini merupakan desa yang secara resmi dibentuk oleh pemerintah melalui program transmigrasi yang dilakukan pada tahun 1981 dengan mendatangkan para transmigran dari berbagai wilayah di Indonesia. Hal ini pula yang menjadikan Desa Banuroja sejak awal masyarakatnya terdiri dari berbagai suku, agama dan budaya yang beradaptasi demi menciptakan kerukunan antarumat beragama.

\section{Metode}

Penelitian ini menggunakan metode penelitian kualitatif yang mana menurut Bogdan dan Taylor merupakan sebuah prosedur penelitian yang menghasilkan data deskriptif berupa ucapan, tulisan dan perilaku dari orang atau subjek yang dapat diamati. ${ }^{11}$ Penelitian ini bertujuan untuk mengetahui bagaimana peran tokoh agama Islam, Kristen, dan Hindu dalam menjaga kerukunan antarumat beragama di Desa Banuroja. Penelitian ini dilakukan di Desa Banuroja, Kecamatan Randangan, Kabupaten Pohuwato, Provinsi Gorontalo dan dilaksanakan selama 3 bulan terhitung dari bulan Februari hingga bulan April 2021.

Sumber data dalam penelitian ini diperoleh dari lapangan yakni melalui hasil wawancara mendalam dengan informan dan observasi. Wawancara dilakukan dengan mengajukan beberapa pertanyaan kepada para tokoh agama dan masyarakat Desa Banuroja serta peneliti melakukan observasi untuk membandingkan data dari hasil wawancara dengan kenyataan yang terjadi di lapangan.

Teknik pengambilan sampel dalam penelitian ini menggunakan teknik purposive sampling, yaitu dengan cara menetapkan ciri khusus yang sesuai dengan tujuan penelitian. ${ }^{12}$ Kondisi Desa Banuroja yang dihuni oleh hingga empat agama sekaligus bukan tidak mungkin memicu masalah maupun konflik agama, maka dari itu penelitian ini dilakukan untuk melihat bagaimana peran yang dijalankan oleh para tokoh agama dalam menjaga kerukunan antarumat beragama di Desa Banuroja. Terdapat dua kriteria informan yaitu: (1) Para tokoh agama yang terdiri dari tokoh agama Islam, Kristen, dan Hindu; (2) Masyarakat Desa Banuroja.

${ }^{10}$ Noe et al., "Realizing Multiculturalism and Social Integration in Banuroja Community". Jurnal Civics: Media Kajian Kewarganegaraan 18, no. 1 (2021): 82-96. https://doi.org/10.21831/jc.v18i1.37983

${ }^{11}$ Rulam Ahmadi, Metodologi Penelitian Kualitatif. Yogyakarta: Ar-Ruzz Media, 2016.

12 Rukin, Metodologi Penelitian Kualitatif. Takalar: Yayasan Ahmar Cendekia Indonesia, 2019. 
Untuk memperoleh validitas data yang tinggi selama penelitian, peneliti menggunakan triangulasi dengan membandingkan atau mengecek ulang derajat kepercayaan suatu informasi yang diperoleh melalui sumber yang berbeda. Teknik analisis data yang digunakan oleh peneliti adalah model analisis interaktif oleh Miles dan Huberman. ${ }^{13}$ Aktivitas dalam analisis data dibagi ke dalam 3 tahap yaitu reduksi data, penyajian data, dan penarikan kesimpulan. Pada tahap reduksi data, setelah peneliti mengumpulkan data di lapangan lalu data tersebut dipilih untuk halhal yang pokok dan memfokuskan hanya pada hal-hal yang penting saja. Hal pokok tersebut di antaranya data monografi desa, hasil wawancara yang mendeskripsikan peran tokoh agama dalam menjaga kerukunan, dan hasil observasi lapangan yang menunjukkan kebenaran dari peran yang dilakukan oleh tokoh agama tersebut. Pada tahap penyajian data, data yang telah direduksi kemudian peneliti sajikan dalam bentuk kalimat dengan menarasikan rekaman hasil wawancara dari informan dan juga peneliti membuat grafik jumlah penduduk berdasarkan suku dan agama yang didapat dari data monografi Desa Banuroja. Terakhir yaitu penarikan kesimpulan untuk menjawab rumusan masalah dalam penelitian ini.

\section{Hasil dan Pembahasan}

\section{Gambaran Umum Desa Banuroja}

Desa Banuroja adalah sebuah desa yang secara administratif terbentuk pada tahun 2003 sebagai hasil pemekaran dari Desa Manunggal Karya. Dilihat dari letaknya, desa ini berada di antara 121 ${ }^{\circ} 788108^{\prime}$ Bujur Timur dan $0^{\circ} 588141^{\prime}$ Lintang Utara yang termasuk dalam wilayah administratif Kecamatan Randangan, Kabupaten Pohuwato, Provinsi Gorontalo. Lahirnya Desa Banuroja diawali dengan adanya program transmigrasi yang dilakukan oleh pemerintah pada tahun 1981. Melalui program tersebut, masyarakat dari berbagai daerah yang terdiri dari latar belakang suku dan agama yang berbeda-beda didatangkan ke wilayah Gorontalo sehingga tidak heran bahwa Desa Banuroja kemudian menjadi wilayah yang heterogen.

Dari komposisi penduduknya, Desa Banuroja memiliki jumlah penduduk 1.177 jiwa dengan 365 Kepala Keluarga (KK). Berdasarkan jumlah penduduk menurut suku bangsa, desa ini dihuni oleh 12 suku (Gambar 1). Banyaknya suku yang menghuni Desa Banuroja menjadi alasan utama mengapa di desa ini terdapat hingga 4 agama yang dianut oleh para masyarakatnya, terdapat beberapa suku yang mayoritas masyarakatnya menganut agama Islam seperti Suku Sasak, Jawa, Gorontalo, Sunda, Bugis, Betawi dan Bajau. Kemudian beberapa suku yang mayoritas masyarakatnya beragama Kristen di antaranya adalah Suku Minahasa, Batak, Flores, dan Toraja. Terakhir adalah suku yang mayoritas masyarakatnya beragama Hindu adalah Suku Bali.

${ }^{13}$ Sugiyono, Metode Penelitian Pendidikan (Pendekatan Kuantitatif, Kualitatif, Dan R\&D). Bandung: Alfabet, 2015. 


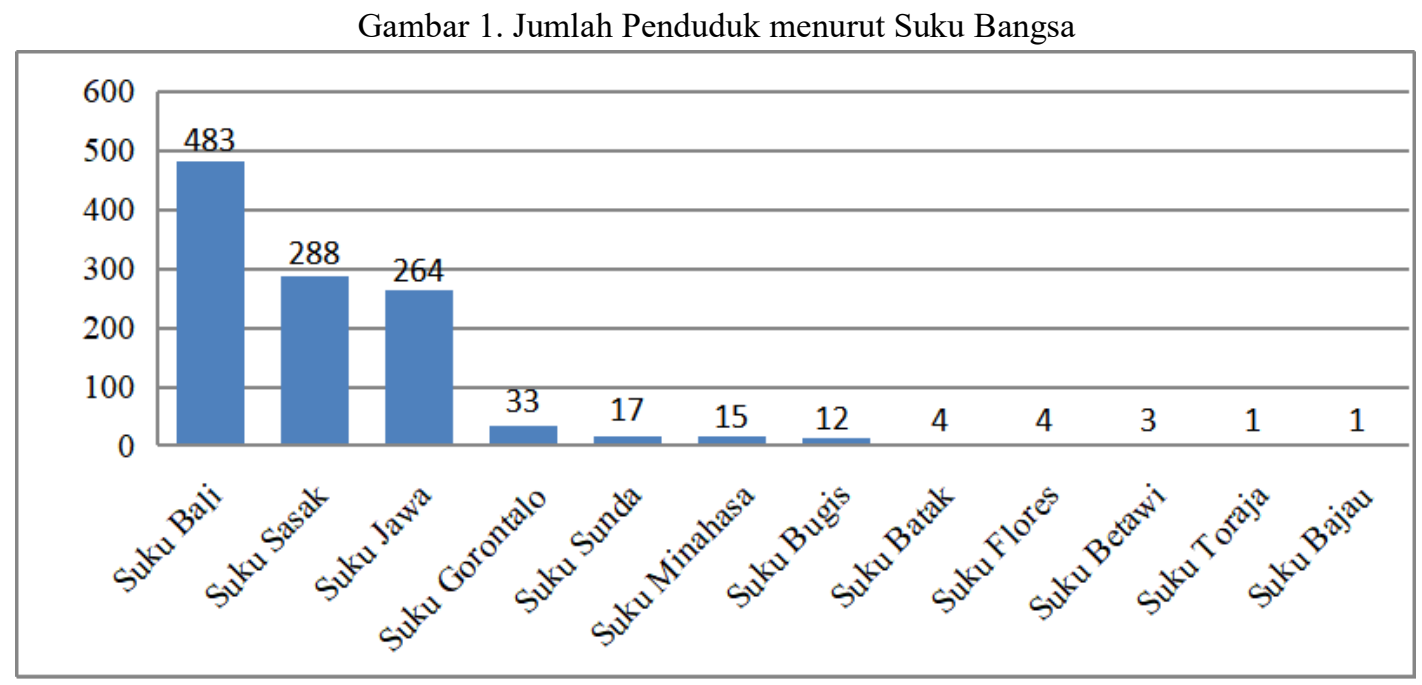

(Sumber: Data Desa Banuroja tahun 2021)

Pada komposisi penduduk menurut agama, mayoritas masyarakat Desa Banuroja memeluk agama Islam, lalu disusul oleh pemeluk agama Hindu, selanjutnya pemeluk agama Kristen dan terakhir pemeluk agama Katolik (Gambar 2).

Gambar 2. Jumlah Penduduk menurut Agama

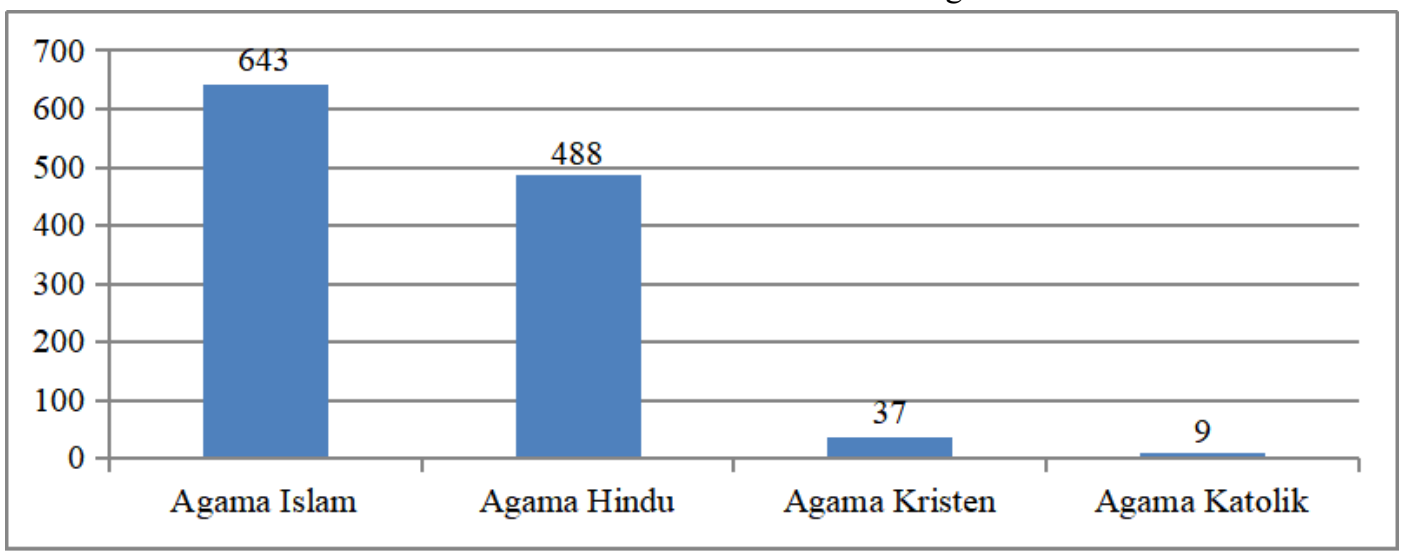

(Sumber: Data Desa Banuroja tahun 2021)

\section{Peran Tokoh Agama Desa Banuroja}

Dalam sebuah lingkungan yang heterogen seperti Desa Banuroja akan dengan mudah muncul berbagai masalah yang dapat memicu terjadinya konflik, sehingga dalam kondisi desa yang dihuni oleh berbagai etnis dan agama maka sangat dibutuhkan toleransi dari para masyarakat agar terciptanya kerukunan antarumat beragama. Mengajarkan masyarakat agar dapat beradaptasi dengan kondisi lingkungan yang heterogen merupakan pilihan yang tepat dalam hal pemeliharaan kerukunan, seperti yang dikatakan oleh Wasil dalam penelitiannya bahwa salah satu cara yang dapat dilakukan adalah dengan menginternalisasi teologi kerukunan pada masyarakat. ${ }^{14}$ Kondisi

${ }^{14}$ Wasil, "Peran Pemuka Agama Dalam Memelihara Kerukunan: Studi Kasus Hubungan Islam Dan Katolik Di Desa Pabian Kabupaten Sumenep." Pascasarjana, Fakultas Ushuluddin, Universitas Islam Negeri Syarif Hidayatullah, 2018. http://repository.uinjkt.ac.id/dspace/handle/123456789/40292 
kehidupan masyarakat Desa Banuroja sekarang ini telah mencerminkan sebagai desa yang pluralis, yang mengerti bagaimana cara menghargai orang lain, cara menghargai perbedaan dari segi etnis maupun agama sehingga berbagai isu yang dapat menyebabkan perpecahan dalam masyarakat bisa diatasi.

Terjaganya kerukunan dalam masyarakat tidak terlepas dari peran para tokoh agama yang selalu mengajarkan pada masyarakat tentang toleransi dan kerukunan antarumat beragama, seperti peran yang dijalankan oleh Nawawi, tokoh agama Islam di Banuroja berikut ini:

"Jadi untuk menjaga kerukunan di Banuroja ini saya itu mengajarkan pada masyarakat apa itu kemanusian lewat ceramah atau kalo lagi ngobrol dengan masyarakat. Saya mengajarkan itu dengan ngasih contoh seperti kalo kita melihat suatu kejadian di jalan raya, ada orang ketabrak motor dan lain sebagainya. Nah mo nolong itu kitanya tidak lagi nanya "ti pak agamanya apa?”...aa maka dari situ yang selalu saya ajarkan pada masyarakat itu yang pertama tentang kemanusiaan, kalo agama itu yang kedua. Karna kalo kemanusiaan sudah dikuasai maka untuk menciptakan kerukunan umat beragama, menciptakan ruang keharmonisan itu Insya Allah sangat-sangat mudah". ${ }^{15}$

Dalam mengajarkan konsep kemanusiaan, Nawawi tidak hanya mengajarkannya ke umat Islam saja tetapi ke semua masyarakat di Desa Banuroja tanpa memandang latar belakang agamanya. Hal tersebut dirasakan langsung oleh Komang yang berasal dari umat Hindu yang mengatakan bahwa:

“...sejak dulu sampe skarang itu masih banyak dari kita para transmigran dari Bali bersekolah di Yayasan Salafiyah Safi'iyah, ilmu yang kita dapat dari yayasan itu tidak hanya ilmu pengetahuan tapi juga slalu diajarkan soal kerukunan. Jadi beberapa kesempatan itu pak ustad Nawawi slalu kasih tau ke kita kalo tinggal di sini (Banuroja) itu harus diutamakan rasa kemanusian, kekeluargaan. Agama dan kesukuan itu urusan kedua". ${ }^{16}$

Pendapat yang serupa juga dituturkan oleh Abdullah dari umat Islam mengenai peran penting dari Nawawi dalam kehidupan antarumat beragama di Desa Banuroja. Berikut penuturan dari Abdullah:

"Kita masyarakat Banuroja itu slalu dikasih nasehat sama pak ustad Nawawi, salah satu alasan kita rukun damai yaa karna kita sering dengar ceramahnya pak ustad. Kalo kita yang Islam kan biasanya denger ceramah itu saat ada acara-acara keagamaan kaya Pengajian Akbar yang dibuat oleh pesantren, juga kalo ada doa memperingati hari kematian gitu sering kasih ceramah juga. Ceramah yang dibawakan pak ustad itu pasti slalu diselipkan soal kerukunan, kekeluargaan dan soal kedamaian makanya kita di sini slalu menjaga hubungan antarsesama". ${ }^{17}$

Dari umat Kristen sendiri yakni Surbakti juga membenarkan bahwa Nawawi sering mengajarkan soal kemanusiaan, berikut penjelasannya:

“...karna sering pak ustad Nawawi bicara soal tolong menolong itu kaya lebih meningkatkan lagi rasa kemanusiaan kita. Contoh nyata ini saya bantu adek ngasih tau

\footnotetext{
${ }^{15}$ Wawancara dengan Nawawi, tokoh agama Islam pada 11 Februari 2021

${ }^{16}$ Wawancara dengan Komang, umat Hindu pada 09 Maret 2021

${ }^{17}$ Wawancara dengan Abdullah, umat Islam pada 22 Februari 2021
} 
rumah pak pendeta Gandey, karna kebetulan rumah saya samping gereja jadi kalo ada orang nanya rumah pak pendeta itu bakal nanya ke saya dan saya pasti nolong orang tersebut". ${ }^{18}$

Kegiatan menyampaikan pesan keagamaan juga dilakukan oleh Gandey, tokoh agama Kristen, ketika memberikan khotbah saat kegiatan peribadatan. Dalam proses memberikan khotbah selalu diajarkan tentang toleransi dan kerukunan melalui potongan-potongan ayat dalam Al-Kitab tentang ajaran saling mengasihi:

"Kalau kita punya keyakinan mengatakan bahwa "kasihilah musuhmu” itu salah satu potongan ayat di Al-Kitab. Kita jabarkan itu pengertiannya bagaimana. Di situ Yesus bilang musuhmu dikasihi apalagi temanmu. Semua orang di sini kita anggap teman. Kita sampaikan ke teman-teman lain kayak saat-saat diskusi, acara, macam yah berkumpul, perpisahan tahun begitu atau pas ada acara-acara orang kawin. Nantinya kita ajarkan ke masyarakat yang bukan dari Kristen dengan cara yang berbeda, secara umum begitu biar tidak bikin salah paham." 19

Pesan keagamaan yang disampaikan oleh Gandey kepada umat Kristen mengenai ajaran saling mengasihi telah tertanam dalam diri mereka, dan ditemukan ketika melihat tindakan dan perilaku masyarakat Banuroja seperti Utami, informan dari umat Kristen, sedang berinteraksi pada sore hari dengan tetangganya yang beragama Islam dan Hindu di depan rumah mereka masing-masing. Kemudian Surbakti informan yang juga dari umat Kristen menunjukan respon yang baik saat peneliti meminta waktunya untuk diwawancarai yang pada saat itu Surbakti sedang sibuk dengan kegiatannya membersihkan pekarangan rumahnya.

Selanjutnya peran dari Wayan tokoh agama Hindu yakni dengan mengajarkan beberapa konsep yang dianut dalam agama Hindu. Beberapa konsep yang ada dalam ajaran agama Hindu memang sangat cocok untuk dipelajari dan diajarkan kepada para masyarakat karena beberapa konsep yang ada tersebut memerintahkan manusia untuk hidup dalam kerukunan dan kedamaian.

“...namanya Tat Twam Asi, Tat Twam Asi itu ee...kamu adalah saya dan saya adalah kamu. Siapa dia? Itu adalah kamu sendiri, jadi saya hormati dia maka sama dengan dia menghormati saya. Ada hubungan timbal balik. Jadi orang lain itu bagaikan cermin bagi kita, ketika kita menghormati seseorang maka orang itu akan melakukan hal yang sama terhadap kita”. ${ }^{20}$

Hasil dari peran yang dijalankan oleh Wayan dapat dilihat dari bagaimana masyarakat yang bukan beragama Hindu menghormati umat Hindu saat perayaan Hari Raya Nyepi yang dilaksanakan pada 14 Maret 2021, pada saat perayaan Nyepi tersebut masyarakat yang bukan beragama Hindu tidak membuat keributan yang mana hal itu merupakan salah satu dari kegiatan Catur Brata Penyepian bagian Amati Lelanguan yakni larangan untuk bersenang-senang. Didapati oleh peneliti kondisi desa sangat sepi dan senyap pada saat melaksanakan kegiatan Amati Lelanguan. Melihat masyarakat yang ikut berdiam diri tidak membuat keributan saat perayaan Nyepi membuktikan bahwa konsep Tat Twam Asi yang diajarkan oleh Wayan telah

\footnotetext{
${ }^{18}$ Wawancara dengan Surbakti, umat Kristen pada 17 Maret 2021

${ }^{19}$ Wawancara dengan Gandey, tokoh agama Kristen pada 17 Maret 2021

${ }^{20}$ Wawancara dengan Wayan, tokoh agama Hindu pada 09 Maret 2021
} 
dipelajari dengan baik oleh masyarakat sehingga masyarakat dapat saling menghormati satu sama lain terutama dalam hal menghormati upacara peribadatan dari masing-masing agama yang ada.

Dari tokoh agama Kristen selain mengajarkan tentang saling mengasihi, Gandey juga menjalankan perannya dengan mengajarkan sikap keterbukaan pada masyarakat. Menurutnya bahwa kondisi desa yang heterogen maka sangat diperlukan sikap keterbukaan satu sama lain sehingga nantinya dapat menjalani kehidupan yang rukun dan damai antar sesama:

“...kalau macam Natal, contohnya rumah ini terbuka sampai jam 12 malam untuk semua orang yang mau berkunjung, tidak memandang dia siapa, mau agama Hindu, Islam atau dia orang Gorontalo, orang Lombok, orang Jawa, orang Sunda, orang Bali bebas masuk pintu terbuka. Kalau kita selalu terapkan hal yang begini maka lama kelamaan masyarakat akan paham tentang apa sih ini toleransi". ${ }^{21}$

Memang setiap perayaan hari besar keagamaan para masyarakat akan saling bersilaturahmi satu sama lain tanpa memandang agama manapun, itu telah menjadi kebiasaan yang terus dipertahankan oleh masyarakat Desa Banuroja tiap tahunnya. Hal ini benar adanya, di mana peneliti menemukan fakta saat peneliti mengunjungi desa saat perayaan Natal tahun 2020 lalu. Didapati rumah Gandey terlihat ramai setelah rangkaian acara peribadatan Natal di gereja selesai, di mana masyarakat yang berkunjung ke rumahnya terdapat beberapa perempuan yang memakai jilbab dan duduk bersama-sama sambil bercerita dengan Gandey di ruang tamu. Peneliti juga menemukan bahwa saat sebelum berlangsungnya perayaan Natal di gereja, terlihat beberapa pemuda yang bukan beragama Kristen membantu mengatur jalan dan parkiran agar proses perayaan Natal dapat berjalan dengan lancar sampai selesai.

Sejalan dengan peran yang dilakukan oleh tokoh agama Kristen, Gandey, dengan mengajarkan sikap keterbukaan, dari tokoh agama Islam, Nawawi, juga menjalankan salah satu cara untuk menjaga kerukunan yaitu dengan menarik perhatian masyarakat. Tujuan dari menarik perhatian di sini agar bisa lebih dekat dengan masyarakat sehingga dalam mentransfer nilai-nilai kerukunan akan mudah dilakukan. Seperti pengalamannya berikut ini:

"Yang pertama yang harus saya lakukan adalah menarik perhatian masyarakat. Seperti kejadian dulu saat saya ceramah dengan suara yang keras, akhirnya ada yang menegur saya dan nanya "kenapa ustad kok ceramahnya gitu?" Saya bilang "tanpa saya kasih keras dulu mana mungkin Bapak kenal saya, dengan sebab saya kasih keras makanya skarang Bapak kenal saya”. Nah karna sudah dekat jadi potensi untuk membimbing dan mengajarkan mereka tentang toleransi lebih mudah. Saya juga tidak ngasih batas pada teman-teman dari sebelah (agama Hindu dan Nasrani) untuk berinteraksi dengan saya, karna itu memudahkan saya untuk ngasih pemahaman pada masyarakat akan pentingnya menjaga komunikasi antarsesama".22

Kedekatan Nawawi dengan masyarakat Banuroja terutama mereka yang beragama Kristen dan Hindu terlihat jelas. Saat peneliti hendak bertemu dengan Nawawi untuk melakukan wawancara, mendapati Nawawi sedang asik berinteraksi dengan seseorang yang memakai pakaian khas Bali yang menandakan orang tersebut beragama Hindu dan berbincang cukup lama. Kejadian tersebut sejalan dengan apa yang diungkapkan oleh Nawawi saat wawancara yang

\footnotetext{
${ }^{21}$ Wawancara dengan Gandey, tokoh agama Kristen pada 17 Maret 2021

${ }^{22}$ Wawancara dengan Nawawi, tokoh agama Islam pada 11 Februari 2021
} 
mengatakan bahwa ia tidak memberi batasan pada masyarakat yang bukan beragama Islam untuk berinteraksi dengannya. Peneliti juga menemukan fakta saat melakukan wawancara dengan Gandey bahwa saat akan membangun rumahnya ia meminta pendapat sekaligus izin dari Nawawi untuk menaruh simbol agama Kristen seperti gambar salib, pohon natal, dan Tuhan Yesus di kaca jendela rumahnya, kemudian Nawawi memberikan izin karena itu adalah hak dari Gandey atas rumahnya sendiri.

Dari tokoh agama Hindu Wayan menjelaskan bahwa terdapat salah satu ajaran penting yang menjadi pegangan bagi umat Hindu dalam menjalani kehidupan bermasyarakat. Pegangan tersebut dijadikan sebagai alat untuk menjaga kerukunan dengan cara diajarkan kepada masyarakat Desa Banuroja:

“...selain itu yang paling utama itu adalah Tri Kaya Parisudha. Tri itu artinya tiga, Kaya itu perbuatan, Parisudha suci. Kita harus mengupayakan tiga perbuatan yang suci yaitu berpikir suci, berkata suci, berbuat suci. Kalimat ini sering saya ajarakan pada masyarakat utamanya umat Hindu. Jadi kalo semua masyarakat dapat mengamalkan tiga perbuatan suci ini maka kerukunan antar umat beragama akan tetap terjaga dengan baik sampe nanti". 23

Konsep tiga perbuatan suci memiliki arti yang luas sehingga tindakan baik sekecil apapun yang dilakukan oleh seseorang dapat termasuk sebagai perbuatan suci seperti yang peneliti temukan di lapangan saat mengamati aktivitas masyarakat Desa Banuroja. Masyarakat Desa Banuroja jika dilihat dari tindakannya yang selalu menerima dengan baik pendatang yang ingin berkunjung ke desa wisata religi tersebut maka dapat dikatakan bahwa mereka telah melakukan satu dari tiga perbuatan suci, yakni berpikir suci, karena mereka tidak pernah berpikiran negatif terhadap pengunjung Desa Banuroja. Selama peneliti berinteraksi dengan masyarakat Banuroja, peneliti mendapati tutur kata yang sopan dan baik dari masyarakat saat peneliti melakukan wawancara atau hanya sekedar mencari informasi. Hal ini menandakan mereka juga telah melakukan perbuatan suci yakni berkata suci karena tutur kata yang baik serta tidak berbohong saat peneliti meminta informasi tertentu seperti menanyakan tempat tinggal para tokoh agama Banuroja. Tindakan menyiksa, menyakiti, apalagi membunuh makhluk entah manusia maupun hewan merupakan tindakan yang menentang perbuatan suci. Selama peneliti melakukan pengamatan tidak pernah ditemukan tindakan-tindakan yang berbahaya tersebut, artinya masyarakat telah memahami sikap baik kepada sesama maupun terhadap makhluk lainnya. Saat melakukan wawancara dengan Wayan pun ia berkata bahwa hewan itu makhluk bernyawa seperti manusia maka hendaknya kita menghargainya agar mereka juga menghargai kita.

Ditambahkan lagi oleh Wayan bahwa peran yang dilakukan untuk menjaga kerukunan antarumat beragama adalah dengan mengajak masyarakat terutama umat Hindu untuk ikut serta pada kegiatan-kegiatan bersama seperti kerja bakti yang rutin diselenggarakan oleh pemerintah Desa Banuroja. Kegiatan kerja bakti tersebut merupakan salah satu cara yang dilakukan untuk menjaga hubungan antarumat beragama di Desa Banuroja. Keterlibatan warga Hindu ini dianggap penting baginya. Seperti yang diungkapkannya berikut:

"Pemerintah desa itu punya kegiatan dia kerja bakti yang melibatkan seluruh warga Banuroja. Nah keikutsertaan warga ini kan adalah suatu kewajiban, kalo ada yang dari

\footnotetext{
${ }^{23}$ Wawancara dengan Wayan, tokoh agama Hindu pada 09 Maret 2021
} 
kita (umat Hindu) tidak ikut akan ada sanksi di organisasinya kita itu berupa uang, tidak hadir kerja bakti Rp. 5.000. kalo tanpa izin yang jelas itu kena Rp. 5.000. Selain itu kalo pelanggaran berat ya itu ada sanksinya, yang paling berat malah dikeluarkan dari organisasi. Nah karna itu anggota kita aktif di organisasi, ndak berani ndak aktif. Kita dalam kerukunan adat itu aktif karna prinsip kita itu kita lahir ditolong orang nanti mati juga ditolong orang, kalo kita tidak mau aktif dengan orang gitu nanti kalo mati siapa yang nolongi. Kalo kita kematian orang Bali lagi di sini memakai sistem upacara adat Ngaben itu perlu teknis banyak, pertolongan orang sekampung itu terlibat. Itu yang penyebab utama kita sadar bahwa kita disuatu saat amat butuh pertolongan orang". ${ }^{24}$

Terkait kerja bakti dan sanksi yang diberlakukan pada organisasi umat Hindu tersebut juga dibenarkan oleh salah satu anggotanya yakni Komang:

"Kerja bakti yang rutin dilakukan di Banuroja ini sangat membantu kita menerapkan kedisiplinan dek, karna kenapa? Soalnya kalo di kita umat Hindu itu kalo ada yang tidak ikut nantinya ada sanksi, yang paling berat itu dikeluarkan dari organisasi kalo sanksi kecil yahhh cuma di denda Rp. 5.000. tapi bukan soal sanski uangnya yang kecil tapi rasa malu kita yang tidak ikut itu makanya semua pasti pada ikut. Kerja bakti ini juga saya rasa bagus karna dengan kegiatan ini kita bertemu dengan teman-teman dari semua agama, nahh terjalin lagi interkasi baik kita dengan mereka". ${ }^{25}$

Tradisi gotong royong yang dilakukan oleh masyarakat Desa Banuroja tidak hanya pada hal-hal yang bersifat umum saja seperti kerja bakti. Gotong royong yang dilakukan juga pada kegiatan keagamaan seperti saling meringankan pekerjaan dari satu agama ketika sedang mempersiapkan sebuah acara, seperti yang diungkapkan oleh Made dari umat Hindu berikut:

“...sebenarnya yaa kerja sama di sini itu tidak selalu cuma kerja bakti aja, jadi kalo ada dari salah satu umat agama akan menyelenggarakan acara gitu yaa kita pasti akan saling bantu. Misal nih dari agama saya Hindu, tokoh agama Hindu itu pasti nanti ngarahin kita umat Hindu untuk bantu kalo dari umat Kristen atau Islam buat kegiatan, nantinya kita di situ bantu-bantu nyiapin kegiatan itu". ${ }^{26}$

Ungkapan Made terkait dengan gotong royong masyarakat Banuroja memang benar adanya, hal tersebut terlihat saat peneliti mengamati jalannya proses perayaan Natal tahun 2020 dan perayaan Galungan 2021. Saat perayaan Natal, peneliti menemukan adanya masyarakat yang bukan beragama Kristen ikut membantu mengatur lalu lintas, parkiran, dan menjaga keamanan selama proses peribadatan berlangsung. Hal yang sama ketika perayaan Galungan terjadi kemacetan di depan Pura utama Desa Banuroja dan akhirnya dibantu oleh masyarakat dari agama Islam dan Kristen untuk mengaturnya. Terakhir peneliti juga mengamati kegiatan yang dilakukan oleh masyarakat selama tiga hari sebelum perayaan Idul Fitri, terdapat tradisi Tumbilotohe (pasang lampu) yaitu tradisi menyalakan lampu botol tetap pada malam 27, 28, dan 29 Ramadhan seluruh masyarakat dari semua agama ikut meramaikan tradisi tahunan tersebut. Tidak hanya itu, masyarakat dan tokoh agama dari lintas agama juga ikut membantu mendirikan Alikusu yaitu gerbang besar yang terbuat dari kayu dan digantung lampu botol serta dihiasi janur kuning yang akan di pasang di depan masjid Banuroja.

\footnotetext{
${ }^{24}$ Wawancara dengan Wayan, tokoh agama Hindu pada 09 Maret 2021

${ }^{25}$ Wawancara dengan Komang, umat Hindu pada 09 Maret 2021

${ }^{26}$ Wawancara dengan Made, umat Hindu pada 22 Februari 2021
} 
Dalam proses interaksi, manusia selalu diwarnai dengan dua hal yakni kerja sama dan konflik di mana kedua hal tersebut merupakan konsekuensi dari proses interaksi yang terjadi dalam kehidupan manusia. Konflik dapat terjadi ketika tujuan dari masyarakat berbeda satu sama lain dan salah satu faktornya adalah adanya perbedaan kebudayaan dan agama dalam masyarakat, seperti halnya Desa Banuroja yang merupakan desa multi agama maka tidak dapat dipungkiri desa ini rawan akan terjadinya potensi konflik. Salah satu permasalahan yang pernah mewarnai kehidupan masyarakat Banuroja adalah konflik antara umat Hindu dan Islam, dalam wawancara dengan Abdullah menuturkan:

"Dulu dek, pernah hampir konflik antara warga dari umat Islam dengan Hindu karna soal babi. Jadi warga Hindu di sini itu pelihara babi dan dibiarkan berkeliaran di desa, nah karna babi ini dibiarkan jadinya masuk ke pekarangan rumah warga Islam ngerusakin tanaman di situ. Yang punya rumah jelas marah kan, nah sama mereka itu sampe dibunuh eh yang punya babi marah akhirnya berkonflik. Tapi untungnya masalah itu bisa dikasih selesai sebelum konflik makin besar, jadi saat itu karna sudah rame saling adu mulut, warga lain lapor sama tokoh agama Islam dan Hindu kemudian saat itu dikasih kumpul yang punya babi sama yang pekarangan rumahnya dirusak oleh babi. Trus musyawarah dilakukan yang dipimpin sama tokoh agama dan akhirnya dibuat kesepakatan dengan mengikat atau mengurung babi dikandang agar tidak berkeliaran di rumah-rumah warga. ${ }^{27}$

Konflik lain juga pernah terjadi di Desa Banuroja yakni konflik kepemilikan tanah atau sengketa lahan antara para transmigran dan penduduk lokal Gorontalo. Melalui pemerintah bahwa status kepemilikan tanah yang sejak tahun 1990-an sudah menjadi permasalahan antara kedua belah pihak menyatakan kalau tanah di desa tersebut telah dihibahkan oleh pemerintah kepada para transmigran untuk Unit Pemukiman Transmigrasi. Permasalahan mulai muncul ketika para penduduk lokal mengklaim bahwa tanah di Desa Banuroja tersebut merupakan tanah yang diwariskan oleh para leluhur mereka sebelum adanya program pemerintah terkait pembangunan Unit Pemukiman Transmigrasi di desa tersebut. Seperti penuturan Ahmadi yang dulu pernah melihat langsung kejadiannya tersebut:

“...masalah sengketa lahan di sini lumayan lama, jadi penduduk asli sini itu slalu datang nuntut kalo tanah ini milik nenek moyang mereka jadi mereka punya hak atas tanah di Desa Banuroja. Karna mereka slalu nuntut itu warga jadi risih, juga sering adu mulut. Nah... akhirnya warga ini lapor sama tokoh-tokoh agama, sama tokoh agama itu penutut tanah sama pemilik tanah diajak ke kantor desa, masing-masing disuruh bawa surat kepemilikan tanah. Setelah di kantor desa penutut ini jelas gak bisa nunjukin surat kepemilikan tanah sedangkan pemilik tanah bisa, yah... akhirnya sejak saat itu penduduk asli yang ngaku-ngaku punya tanah di sini udah gak nuntut-nuntut lagi ${ }^{28}$

\section{Analisis: Terjaganya Kerukunan Antarumat Beragama di Desa Banuroja}

Berdasarkan data dari hasil wawancara yang dilakukan dengan beberapa informan ditemukan bahwa para tokoh agama melakukan berbagai cara untuk menciptakan kondisi Desa Banuroja

\footnotetext{
${ }^{27}$ Wawancara dengan Abdullah, umat Islam pada 22 Februari 2021

${ }^{28}$ Wawancara dengan Ahmadi, umat Islam pada 22 Februari 2021
} 
yang rukun serta menjaganya agar tetap damai. Hal ini dilakukan karena sadar akan lingkungan yang mereka tempati terdapat berbagai macam perbedaan di dalamnya. Oleh sebab itu, sebagai seorang yang dipercaya menjadi tokoh agama maka mereka pun sadar akan peran dan tanggung jawab sebagai pemimpin pada kegiatan peribadatan dan dalam kehidupan bermasyarakat.

Relevan dengan hal tersebut, Parsons melalui Teori Fungsionalisme Struktural miliknya mengembangkan sebuah skema yang disebut AGIL. Menurut Parsons agar sebuah sistem sosial dapat bertahan maka harus memenuhi empat prasyarat fungsional yaitu Adaptation (Adaptasi), Goal attainment (Pencapaian Tujuan), Integration (Integrasi), dan Latency (Pemeliharaan Polapola) atau yang biasa dikenal sebagai skema AGIL. Dalam pandangan Parsons tentang sistem sosial adalah haruslah memiliki fungsi, fungsi di sini berkaitan dengan segala bentuk kegiatan yang diarahkan pada pemenuhan kebutuhan dari sebuah sistem. ${ }^{29}$ Mengacu dari skema AGIL ini, maka kemudian skema tersebut akan digunakan untuk mengkaji bagaimana peran dari para tokoh agama untuk menjaga kerukunan antarumat beragama di Desa Banuroja.

Pada prasyarat pertama Adaptation (adaptasi) yaitu sebuah sistem harus mempunyai kemampuan untuk dapat beradaptasi atau menyesuaikan diri dengan lingkungannya. Berkenaan dengan prasyarat tersebut, para tokoh agama menjalankan perannya dengan mengajak para masyarakat untuk sama-sama beradaptasi terhadap kondisi Desa Banuroja yang heterogen agar kemudian dapat terjaga kehidupan yang rukun antarumat beragama. Pada tokoh agama Islam yakni Nawawi, peran yang dijalankannya terkait adaptasi adalah mengajarkan kepada para umat Islam melalui dakwah serta mengajarkannya pula pada umat dari agama lain tentang "Kemanusiaan". Bagaimana kemudian sesama makhluk hidup tanpa memandang latar belakang agama tetap saling menolong satu sama lain ketika ada yang membutuhkan bantuan. Hal yang serupa juga dilakukan oleh Gandey, tokoh agama Kristen, ia mengatakan dalam ajaran Kristiani terdapat satu potongan ayat yang berbunyi "Kasihilah musuhmu" lalu kemudian potongan ayat tersebut yang selalu diajarkan kepada umat Kristen dan diajarkan pula kepada masyarakat dari agama lain tentang bagaimana cara untuk hidup rukun. Tidak jauh berbeda dari tokoh agama Islam dan Kristen, Wayan, tokoh agama Hindu, juga melakukan hal yang sama. Dalam mengajak masyarakat terutama umat Hindu untuk beradaptasi dengan kondisi lingkungan yang terdapat banyak perbedaan beliau sering mengajarkan tentang "Tat Twam Asi" yang memiliki arti "Kamu adalah saya, dan saya adalah kamu". Maksudnya adalah dalam menjalani kehidupan bermasyarakat harus ada hubungan timbal balik yang baik antar sesama. Beliau mengatakan bahwa orang lain bagaikan cermin bagi kita, ketika kita menghormati seseorang maka orang tersebut akan melakukan hal yang sama juga kepada kita.

Prasyarat kedua adalah Goal attainment (pencapaian tujuan) yaitu sebuah sistem harus merumuskan berbagai cara yang dapat dilakukan untuk mencapai tujuan yang ingin diraih oleh sistem tersebut. Pada prasyarat ini, para tokoh agama mempunyai satu tujuan yang sama yakni menjaga kerukunan antarumat beragama di Desa Banuroja yang sudah ada sejak dulu. Untuk mencapai tujuan bersama tersebut, tokoh agama Kristen, Gandey, mengajarkan sikap keterbukaan pada masyarakat. Cara ia mengajarkan sikap keterbukaan adalah dengan memulai dari dirinya sendiri yaitu dicontohkan ketika perayaan hari raya Natal, ia akan membuka lebar-lebar pintu rumahnya untuk menyambut masyarakat dari agama mana pun yang ingin bersilaturahmi

${ }^{29}$ Akhmad Rizqi Turama, "Formulasi Teori Fungsionalisme Struktural Talcott Parsons."EUFONI : Journal of Language, Literary and Cultural Studies $2, \quad$ no. $2 \quad$ (2018): 58-69. http://www.openjournal.unpam.ac.id/index.php/EFN/article/view/5178/3661. 
kepadanya. Jika hal kecil seperti ini terus dilakukan maka lama kelamaan masyarakat akan memahami tentang toleransi, langkah ini juga dianggap sangat efektif dalam hal menjaga kerukunan antarumat beragama. Selaras dengan apa yang dilakukan oleh tokoh agama Kristen, tokoh agama Hindu Wayan juga memiliki cara untuk menjaga kerukunan yaitu dengan mengajarkan pada masyarakat dari agama mana pun tentang "Tri Kaya Parisudha" yang artinya tiga perbuatan suci yakni: 1) Berfikir suci, 2) Berkata suci, dan 3) Berperilaku suci. Menurut beliau jika seluruh masyarakat dapat mengamalkan tiga perbuatan suci tersebut maka kerukunan antarumat beragama akan tetap terjaga dengan baik sampai nanti. Tidak ketinggalan pula langkah yang diambil oleh tokoh agama Islam, Nawawi, yaitu dengan menarik perhatian masyarakat dan tidak memberi batasan pada masyarakat dari agama mana pun. Karena ketika ikatan antara individu dengan kelompok sudah sangat dekat maka akan mudah baginya untuk membimbing dan mengajarkan mengenai toleransi serta memberi pemahaman pada masyarakat untuk tetap menjaga komunikasi antar sesama.

Prasyarat ketiga adalah Integration (Integrasi) yaitu sebuah sistem harus dapat mengatur hubungan antar bagian yang menjadi komponennya. Prasyarat ini menuntut tiap umat beragama untuk saling menjalin hubungan dan komunikasi yang baik agar kerukunan dapat tetap terjaga. Mengacu dari hal tersebut, langkah yang diambil oleh tokoh agama Hindu Wayan adalah mengajak masyarakat terutama umat Hindu untuk ikut serta pada kegiatan kerja bakti yang rutin diselenggarakan oleh pemerintah Desa Banuroja. Menurutnya kegiatan kerja bakti ini merupakan salah satu cara untuk menjaga hubungan antarumat beragama di Desa Banuroja. Tokoh agama Islam dan Kristen juga mengambil langkah yang sama untuk menjaga hubungan antarumat beragama, yakni dengan membantu jika ada salah satu agama yang akan melaksanakan kegiatan. Karena ketika mengajak umat untuk mempermudah pekerjaan dari umat lain, maka yang dilakukan saat itu adalah sedang memperkuat hubungan dengan umat lain, yang menandakan sedang terbangunnya integrasi dalam sebuah sistem sosial.

Prasyarat keempat adalah Latency (Pemeliharaan Pola-pola) yaitu sebuah sistem harus dapat memelihara, melengkapi dan memperbaiki baik motivasi individual maupun pola-pola kultural. Pada prasyarat terakhir ini, untuk memelihara pola-pola yang telah ada di Desa Banuroja para tokoh agama mengambil langkah yang sama yaitu selalu mendoktrin masyarakat untuk tidak gampang terpancing pada isu-isu yang berbau agama. Dikatakan oleh para tokoh agama bahwa letak geografis Desa Banuroja yang berdekatan dengan wilayah konflik yaitu Poso, Sulawesi Tengah akan dengan mudah membuat masyarakat terpancing mengenai masalah atau isu yang berbau agama. Para tokoh agama selalu menekankan pada masyarakat untuk menjadikan konflik yang terjadi di Poso tersebut sebagai bahan pembelajaran dan lebih meningkatkan lagi sikap toleransi antar sesama. Beberapa masalah yang berbau agama yang pernah terjadi di Indonesia seperti salah satunya adalah kasus penistaan agama yang dilakukan oleh Basuki Tjahaja Purnama pada Pilkada DKI Jakarta tahun 2017 malah semakin membuat para tokoh agama mempunyai tekad yang kuat untuk terus mengajak masyarakat dalam hal meningkatkan sikap toleransi dan menjaga kehidupan yang rukun antarumat beragama di Desa Banuroja.

\section{Simpulan}

Tekad yang kuat dari para tokoh agama untuk menjaga kerukunan antarumat beragama sangat terlihat jelas. Peran yang dijalankan oleh tokoh agama Islam, Kristen, dan Hindu demi 
membangun toleransi masyarakat dan menjaganya agar tercipta kehidupan yang harmonis merupakan sumbangsih besar dari para tokoh agama untuk Desa Banuroja. Peran yang dilakukan oleh para tokoh agama yang dimulai dari proses adaptasi yakni bagaimana kemudian para tokoh agama mengajarkan masyarakat untuk bisa saling tolong menolong tanpa melihat latar belakang agama seseorang melalui ajaran Islam tentang "Kemanusiaan", potongan ayat Al-Kitab "Kasihilah Musuhmu" dan ajaran Hindu yang disebut "Tat Twam Asi". Kemudian peran para tokoh agama pada proses pencapaian tujuan seperti mengajarkan sikap keterbukaan, mengajarkan tiga perbuatan suci yakni: 1) Berfikir suci, 2) Berkata suci, 3) Berperilaku suci, dan memberi pemahaman pada masyarakat untuk tetap menjaga komunikasi antarsesama. Peran para tokoh agama dalam menciptakan integrasi antarumat beragama dapat terlihat pada ajakan kepada masyarakat untuk mengikuti berbagai kegiatan sosial seperti kerja bakti yang diselenggarakan oleh pemerintah desa dan saling membantu mempermudah pekerjaan dari umat lain ketika umat lain tersebut sedang mengadakan kegiatan. Peran yang terakhir dari para tokoh agama adalah memelihara pola-pola yang telah ada di Desa Banuroja yaitu dengan selalu memperingatkan masyarakat untuk tidak mudah terpancing mengenai isu-isu atau masalah yang dianggap sensitif dan bernuansa agama sehingga kehidupan masyarakat Banuroja yang sebelumnya telah rukun dan damai dapat tetap terjaga dengan baik.

\section{Daftar Pustaka}

Ahmadi, Rulam. Metodologi Penelitian Kualitatif. Yogyakarta: Ar-Ruzz Media, 2016.

Angkouw, Gabriel James, and Iky Sumarthina Putri Prayitno. "Scriptural Reasoning: Peran Kitab Keagamaan Dalam Pendidikan Agama Multikultural Di Young Interfaith Peacemaker Community Indonesia." Al-Adabiya: Jurnal Kebudayaan Dan Keagamaan 15, no. 01 (June 5, 2020): 69-91. https://doi.org/10.37680/adabiya.v15i01.410.

Aziz, Zahara, Amla Salleh, and Hardiana Ema Ribu. "A Study of National Integration: Impact of Multicultural Values." Procedia - Social and Behavioral Sciences 7, no. 2 (2010): 691-700. https://doi.org/10.1016/j.sbspro.2010.10.094.

Baihaqi, M. Adib. "Peran Tokoh Agama Dalam Menjaga Kerukunan Antar Umat Beragama (Komunikasi Kelompok Pada Dusun Thekelan, Desa Batur, Kecamatan Getasan, Kabupaten Semarang Tahun 2018).” Skripsi. Institut Agama Islam Negeri Salatiga, 2018.

Lestari, Dwi. "Upaya Tokoh Masyarakat Dan Tokoh Agama Dalam Menerapkan Pendidikan Multikultural Antar Agama Di Desa Menjing Kecamatan Jenawi Kabupaten Karanganyar Tahun 2019.” Institut Agama Islam Negeri Surakarta, 2019.

Noe, Wahyudin, Novia Wahyu Wardhani, Sitirahia Ji Umar, and Rasid Yunus. "Realizing Multiculturalism and Social Integration in Banuroja Community." Jurnal Civics: Media Kajian Kewarganegaraan 18, no. 1 (2021): 82-96. https://doi.org/10.21831/jc.v18i1.37983.

Rukin. Metodologi Penelitian Kualitatif. Takalar: Yayasan Ahmar Cendekia Indonesia, 2019.

Sahfutra, Suryo Adi. "Konflik Dan Bina Damai Masyarakat Multirelijius: Studi Masyarakat Turgo Lereng Merapi Yogyakarta." MUHARRIK: Jurnal Dakwah Dan Sosial 2, no. 2 (November 13, 2019): 71-97. https://doi.org/10.5281/ZENODO.3540507.

Setyawan, Agus. "Dakwah Yang Menyelamatkan: Memaknai Ulang Hakikat Dan Tujuan Da'wah Islamiyah." Al-Adabiya: Jurnal Kebudayaan Dan Keagamaan 15, no. 02 (2020): 189-99. https://doi.org/https://doi.org/10.37680/adabiya.v15i02.487. 
Sugiyono. Metode Penelitian Pendidikan (Pendekatan Kuantitatif, Kualitatif, Dan R\&D). Bandung: Alfabeta, 2015.

Turama, Akhmad Rizqi. "Formulasi Teori Fungsionalisme Struktural Talcott Parsons." EUFONI : Journal of Language, Literary and Cultural Studies 2, no. 2 (2018): 58-69.

Ulya, Inayatul. "Pendidikan Islam Multikultural Sebagai Resolusi Konflik Agama Di Indonesia." Fikrah 4, no. 1 (2016): 20. https://doi.org/10.21043/fikrah.v4i1.1663.

Wahab, Abdul Jamil. Harmoni Di Negeri Seribu Agama (Membumikan Teologi Dan Fikih Kerukunan). Jakarta: PT Elex Media Komputindo, 2015.

Wasil. "Peran Pemuka Agama Dalam Memelihara Kerukunan: Studi Kasus Hubungan Islam Dan Katolik Di Desa Pabian Kabupaten Sumenep." Universitas Islam Negeri Syarif Hidayatullah, 2018.

Yani, Tri Wibowo; Muhammad Turhan. "Peran Tokoh Agama Dalam Menjaga Kerukunan Antar Umat Beragama Di Desa Sekaran Kecamatan Kayen Kidul Kabupaten Kediri." Kajian Moral Dan Kewarganegaraan 02, no. 04 (2016): 844-58. 